\title{
CURRENT STATE AND PERSPECTIVE \\ FOR THE DEVELOPMENT OF THE BEEKEEPING MARKET IN THE WORLD AND UKRAINE
}

\author{
Averchev O. V.
}

\section{INTRODUCTION}

Articulation of issue. Beekeeping is an industry that has the potential for development. In Kherson region the production of honey and the regional union of beekeepers are actively developing.

Beekeeping is a long sought tradition of the people and only in the early 19 th century it became a branch of agriculture. At the present time, beekeeping as an industry is engaged not only in the breeding of bee families and the production of products of their own origin, but also in the use of bees for the plant pollination of entomophilic crops. Ukraine is a country of intensive agriculture, where almost half of crop cultivation requires cross-pollination. Bees give us honey, wax, flower pollen, milky milk, bee-glue, bee poison, drone larvae homogenate. Moreover, recently Apis Mellifera has been used in medicine (bodies of dead bees).

Actual scientific researches and issues analysis. The development of the market for agricultural products and the improvement of the efficiency of their production are the subject of attention in the work of many domestic scientists. Research for the efficient functioning of the beekeeping industry and development of the beekeeping market at various historical stages was carried out by A.N. Yatsenko, V.L. Gritsenko, D.B. Juchenko, A.A. Christenko and others. However, despite the scientific advances that have been made, today the questions of establishing organizational prerequisites and economic mechanisms for the functioning of the beekeeping market in Kherson area and the realization of Ukraine's European integration aspirations; It is the above that determines the relevance of the study.

Purpose of the article. Conduct a comprehensive analysis of the current situation and prospects for the development of the beekeeping market in Ukraine and Kherson region. To make a detailed analysis of the main problems of the Ukrainian beekeeping sector, which need to be solved immediately and to define future directions of development. 


\section{The current state of beekeeping development in Ukraine and the world}

In recent years Ukraine has become a reliable stakeholders in the world market of beekeeping products.

In the area of honey production, Ukraine ranks first in Europe and fifth in the world, officially producing almost 70,000 tons of honey. The producers themselves account for more than 100,000 tons. This represents 5-6 per cent of world production. Our country ranks third among world exporters, behind only China and Argentina. The objects of beekeeping are worker bees, queen bees, drones, bee families, which are bred on tribal and commodity bees (Law of Ukraine "On beekeeping").

The following are subject to beekeeping irrespective of their form of ownership:

1) tribal and commercial apiaries and hive broods chamber;

2) factories producing equipment and beekeeping equipment;

3) enterprises, establishments and organizations for the production, processing and sale of beekeeping products and preparations therefrom;

4) the Beekeeping Certification Laboratory;

5) scientific institutions, educational institutions, research farms that deal with beekeeping. (Art. 4 of the Law of Ukraine "On beekeeping") ${ }^{1}$.

The subjects of beekeeping also include unions, associations and other associations whose activities are related to beekeeping, as well as agricultural producers who produce and process beekeeping products. The inhabitants have every chance of merging into public beekeeper organizations of their own free will, in order to satisfy their collective interests in the development of beekeeping.

Ukraine has a extensive feeding base which is not yet fully used. The medospheres are unstable, the productivity of beekeepers remains low, and most bees lack mechanization of labour-intensive production processes. In order to increase the marketability and profitability of bee herders, it is necessary to have theoretical knowledge and practical skills in the care of bee families and to keep them during wintering. Farm specialists play a leading role in increasing the profitability of the industry. Unlike most farm animals, bees not only collect food for themselves in nature, but also process it for longterm storage, vigorously guard against pests and enemies, and regulate their consumption in summer and winter. Beekeepers can live and reproduce in tree hollows without human intervention ${ }^{2}$.

\footnotetext{
${ }^{1}$ About beekeeping. URL: https://zakon.rada.gov.ua/

${ }^{2}$ Halimov S.M. (2019). Technology of production of the beekeeping produces. Mykolaiv: MNAU, 107 p.
} 
World honey production is $1,500,000$ tons per year, and Ukraine accounts for 5 per cent. Since 2008, Ukraine has ranked first among European countries for honey production (with a gross levy of 75 thousand tons) and fourth after world leaders such as China (367 thousand tons), Turkey (81,4 thousand tons) and Argentina (81 thousand tons). The total number of people who raise bees and produce honey is about 700,000 this is 1.5 per cent of the population of the country ${ }^{3}$. Honey consumption in Ukraine is $1.2 \mathrm{~kg}$ per year, which is one of the highest rates in the world. Also among the leaders are Australia (1.6 kg per year), Greece (1.4) and Germany $(1.1 \mathrm{~kg})^{4}$.

Ukraine is on the list of leading countries in the production and export of honey along with such countries as the USA, China, Argentina, and India. However, despite this fact, it is beekeeping in the country that is in a better position than a full-fledged agricultural sector.

President of Ukraine Leonid Kuchma signed the Law of Ukraine "On beekeeping" The Act was signed on February 22, 20005. The regulatory activity of the industry is more ensured by other normative acts than by this Law, including "Rules of importation into Ukraine and exportation of bees and beekeeping products", "Procedure of registration of bees" ", "Procedure for issuing an apiary veterinary-sanitary passport" etc.

Beekeeping is important as an effective means of increasing yields and improving the quality of fruits, vegetables, legumes, technical crops and other crops. It can therefore be seen as a significant environmental and economic factor in agricultural production.

The main market for Ukrainian honey is the European Union. Among the main exporters are Germany, Poland and Belgium. According to Ministry of Agrarian Policy and Food of Ukraine, in 2018 exports of honey from Ukraine fell by more than 25 per cent and as a result, Ukraine lost the position of the third country - exporter of honey in the world.

Recently, thanks to the creation of public organizations introducing modern developments and the latest technologies among beekeepers, which in turn help to increase the profitability of the apiary, the popularity of beekeeping in Ukraine is rapidly gaining momentum.

${ }^{3}$ The World Honey Market and Ukraine. URL: http://www.souz-inform.com.ua/ index.php?language $=$ ukr\&menu=article/honey_market_review

${ }^{4}$ Vitalii Kuksa (2006). If in Ukraine there will be no fat, we will eat honey «Mirror of the Week», № 31

${ }^{5}$ About beekeeping. URL: https://zakon.rada.gov.ua/

${ }^{6}$ Regulations on the import into and export from Ukraine of bees and bee products. URL: https://zakon.rada.gov.ua/

7 The procedure for the registration of apiary. URL: https://zakon.rada.gov.ua/ 
The Public Union "All-Ukrainian Public Association" Union of Beekeepers of Ukraine ", has made a great contribution to the development of the industry in this direction.

Thanks to the hard work of such organizations, it is hoped that in the near future there will be large industrial apiary in Ukraine that will be able to compete with the leading industrial apiary of the world.

Due to low economic profitability, most players in the market are losing money, and the excess production of sunflower honey has a negative impact on the development of beekeeping.

The main problems of cooperation with agronomists are related to the treatment of chemicals that poison bees. Agribusiness often disregards plant treatment regulations that are established by law and does not inform beekeepers of the use of herbicides and other additives during the pollination process.

When collecting nectar, the beekeeper receives from 50-200 UAH / 1 hectare. However, in the case of poisoning of bees, it is only possible to prove the truth and obtain compensation from the farmer, provided that they are pre-registered and have a veterinary passport ${ }^{8}$.

Kherson region has all conditions for development of beekeeping geographical location, natural and climatic conditions, abundance of honey in forests, steppes and fields of Kherson area. Southern honey has special taste and delicate structure. Well-organized bee pollination increases by 30-60 per cent yields of fruit and cucumber crops, sunflower, rapeseed, etc.

In order to protect the rights and legitimate interests of beekeepers of the Kherson region in 2017 public organization "Union of Beekeepers of the Kherson region" was established.

The most apiary is in the farm "Tavriiskyi pasichnyk", which is also engaged in honey processing. There are about 200 bee families. However, the production of honey in this farm isn't important. It is the only one in the region of apiary that is engaged in breeding tribal bees of the Ukrainian steppe breed and selling bee packets - and it is the main business of this farm. And here they develop craft production - make honey souffles ${ }^{9}$.

\section{Building economic resilience of beekeeping enterprises}

2017 Ukraine exported about 68 thousand tons of honey. 2018 it decreased to 49,4 thousand tons. The main reason for this was the poisoning of bees by plant protection agents. This applies in particular to the violation of

\footnotetext{
${ }^{8}$ The major problems of the beekeeping. URL:https://aggeek.net/

${ }^{9}$ Beekeeping of the Kherson area. URL: https://khoda.gov.ua/
} 
technological requirements for plant protection treatment and the failure of bees to communicate about such treatment ${ }^{10}$.

Exports of honey from Ukraine rose by 12,7 per cent in 2019 , to 55,6 thousand tons. Total exports for the first quarter of 2020 amounted to 14,9 thousand tons exceeded those for 2019 and 2018 by 16 per cent and 47 per cent respectively ${ }^{11}$.

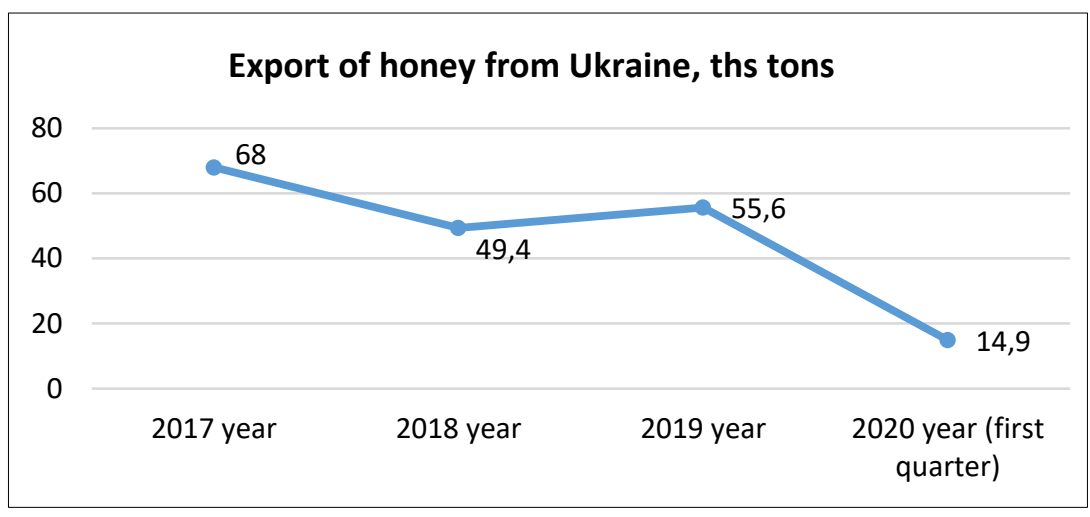

Fig. 1. Export of honey from Ukraine

As of the State Statistics Service of Ukraine and the State Fiscal Service of Ukraine.

The export of honey from Kherson area in 2019 amounted to 2599,5 tons, which is 0,11 per cent of the total export of agro-industrial products from the area in the said period. In 2018, Kherson honey was exported to 8 countries, and in 2019 - to already 11 countries, 8 of which are EU countries: Austria, Belgium, Bulgaria, Estonia, Spain, Germany, Poland and Czech Republic. In addition, Kherson honey was exported to Norway, the United States and Canada in 2019. The largest volume of honey (78,4 per cent) was exported to Spain - 846,2 tons.

Exports of honey from Kherson region in the first half of 2020 amounted to 1582,2 tons. In comparison with the volume of exports of honey for the corresponding period 2019 (1356,2 tons), the trend is positive, with exports of honey increasing by 16,7 per cent in the first half of the current year.

Honey was exported this year to three EU countries: Estonia, Germany, Czech Republic. The largest volume of honey ( 88,8 per cent) was exported to Germany $-1405,4$ tons.

${ }^{10}$ Beekeeping of the Ukraine. URL: http://naas.gov.ua/
${ }^{11}$ Economic truth. URL: https://www.epravda.com.ua/ 
Ukraine produces about 70-80 thousand tons of honey per year, exceeds the volume of exports and consumption of this product on the domestic market and leads to stockpiling. About this stated director of development "AskaniaPak" Viktor Ivanchenko, informs "Interfax-Ukraine".

According to Viktor Ivanchenko, the estimated volume of honey production in Ukraine is $70-80$ thousand tons per year. Ukraine produces more honey than it can absorb in the domestic market and sell for export, and these residues are transferred from year to year. According to calculations, the beekeepers still have a total of 35 to 40 thousand tons.

For the first half of 2020, the forecast for sending honey for export was 20 to 25 thousand tons and 15,000 tons were to be shipped for the following year.

Besides, according to the estimates of "Askania-Pak", the volume of honey production in Ukraine has been decreasing by 5 per cent in the last two years due to bad weather conditions.

In addition, since the start of the season, purchase prices for honey in Ukraine have fallen by almost 22 per cent - to $32 \mathrm{UAH} / \mathrm{kg}$ honey.

Today, it is not exporters who influence the price decline, but beekeepers. More honey is produced in Ukraine than can be exported or accepted on the domestic market. Ukraine started the season 2019/20 year with a purchase price of $32 \mathrm{UAH} / \mathrm{kg}$ honey, then the price fell to $25 \mathrm{UAH} / \mathrm{kg}$. The purchase price is close to the production cost of honey. Therefore we can see a crisis in the production of honey ${ }^{12}$.

In March of this year, the first of a series of planned forums was held on the theme: "Development of the beekeeping industry. Interaction of beekeeper-agrarian-power under the leadership of Deputy Minister of Economic Development, Trade and Agriculture of Ukraine Taras Vysotsky and Sergey Glushchenko. Representatives of State Service of Ukraine on Food Safety and Consumer Protection (SSUFSCP) Professional Associations, Business and International Experts took part in the event.

Current issues in the beekeeping industry were considered, in particular:

1) characteristics of the 2020 season;

2) state support for the sector;

3) simplifying the registration of beers and hygienic requirements for them;

4) state supervision and control of plant protection and veterinary medicine;

5) the export of domestic honey;

6) providing scientific expertise and training for the beekeeping industry;

7) legislative changes.

${ }^{12}$ Honey overproduction in Ukraine. URL: https://agropolit.com 
From the business side, there was a need to strengthen legislative controls on pesticide trafficking, the use of PPP (plant protection products) to prevent pesticide poisoning of bees and the preservation of the environment, and the importance of effective communication between beekeepers and agribusinesses has also been emphasized.

Ukraine has a budget programme called "Financial support for agricultural producers", which provides for support for the beekeeping sector in the following areas: compensation for the cost of tribal bees and beekeepers; up to 50 per cent of the cost, but not more than UAH 500 per beekeeper and UAH 100 per female bee. A special budget subsidy of 200 UAH per bee family is also provided to the owners of bees with 10 to 300 beekeepers.

In October, during a meeting with the Deputy Minister of Economic Development, Taras Vysotskyi and representatives of regional departments responsible for the development of the agro-industrial complex of Ukraine considered the expected results of applications by farmers for State support in the areas of beekeeping and gardening.

Now under the program "State support for the development of animal husbandry and processing of agricultural products" according to information of areas adopted documents and can be charged a subsidy for maintenance of beekeeping (200 UAH per bee family) for the amount of almost 240 million UAH.

According to Deputy Minister Taras Vysotskyi, 110 million UAH were planned to support the beekeeping industry. The number of applications exceeds the amount planned by more than twice. This shows that in Ukraine at least 10,000 beekeepers that are officially registered work transparently and can benefit from State support ${ }^{13}$.

The Ministry of Economic Affairs has submitted to the Government a programme of support for the sector for 2020, which includes a grant of $200 \mathrm{UAH}$ per bee family.

The grant is granted, on a non-refundable basis, to natural persons and economic entities that own bees, for cash in the current year from 10 to 300 bee-keepers at a rate of $200 \mathrm{UAH}$ per bee family.

If the beekeeper is more than 300 , the maximum subsidy is $60,000 \mathrm{UAH}$ is one recipient.

In order to receive the grant for beekeeping, individuals had to register the apiary with the local authorities before the end of September and go to the State Veterinary Medicine Hospital to obtain the apiary veterinary passport. It was also necessary to register with the State Register of Capacity as a market operator and open an account at any bank institution ${ }^{14}$.

\footnotetext{
${ }^{13}$ Apiary is strong. URL:https://pasika.pp.ua/

${ }^{14}$ Resolution of the Cabinet of Ministers of Ukraine. № 107. URL: http://search.ligazakon.ua/
} 
Number of bee colonies in Kherson regions

\begin{tabular}{|l|c|}
\hline \multicolumn{1}{|c|}{ Regions } & $\begin{array}{c}\text { Number of } \\
\text { bee colonies }\end{array}$ \\
\hline BERYSLAVSKYI & 1525 \\
\hline BILOZERSKYI & 1385 \\
\hline VELYKOOLEKSANDRIVSKYI & 3870 \\
\hline VELYKOLEPETYSKYI & 2811 \\
\hline VERKHNOROHACHYTSKYI & 427 \\
\hline VYSOKOPILSKYI & 1803 \\
\hline HENICHESKYI & 1879 \\
\hline HOLOPRYSTANSKYI & 1656 \\
\hline HORNOSTAIVSKYI & 367 \\
\hline IVANIVSKYI & 719 \\
\hline KALANCHATSKYI & 1027 \\
\hline KAKHOVSKYI & 2153 \\
\hline NOVA KAKHOVKA & 466 \\
\hline KHERSON & 757 \\
\hline NYZHNOSIROHOZKYI & 1928 \\
\hline NOVOVORONTSOVSKYI & 1975 \\
\hline NOVOTROITSKYI & 2092 \\
\hline SKADOVSKYI & 315 \\
\hline OLESHKIVSKYI & 1515 \\
\hline CHAPLYNSKYI & 1190 \\
\hline ALL & $\mathbf{2 9 8 6 0}$ \\
\hline
\end{tabular}

As of the State Statistics Service of Ukraine and the State Fiscal Service of Ukraine.

The honey market is particularly important for the Ukrainian economy, as it is the largest producer of honey in Europe and the fifth largest exporter in the world. Since 2010, exports of honey have increased sevenfold, resulting in higher export earnings and higher incomes for people engaged in honey production and processing. The European Union is the largest market for Ukrainian honey, accounting for about 75 per cent of its exports.

In 2019, exporters noted a glut in the market due to a significant increase in the production of honey, resulting in pressure from importers to lower prices. Thus, while the US imports 9 per cent more honey in the first six months of 2019 than in the same period last year, the total value of imports fell by 7 per cent, indicating a decline in import prices. This is due to increased supplies from China. 


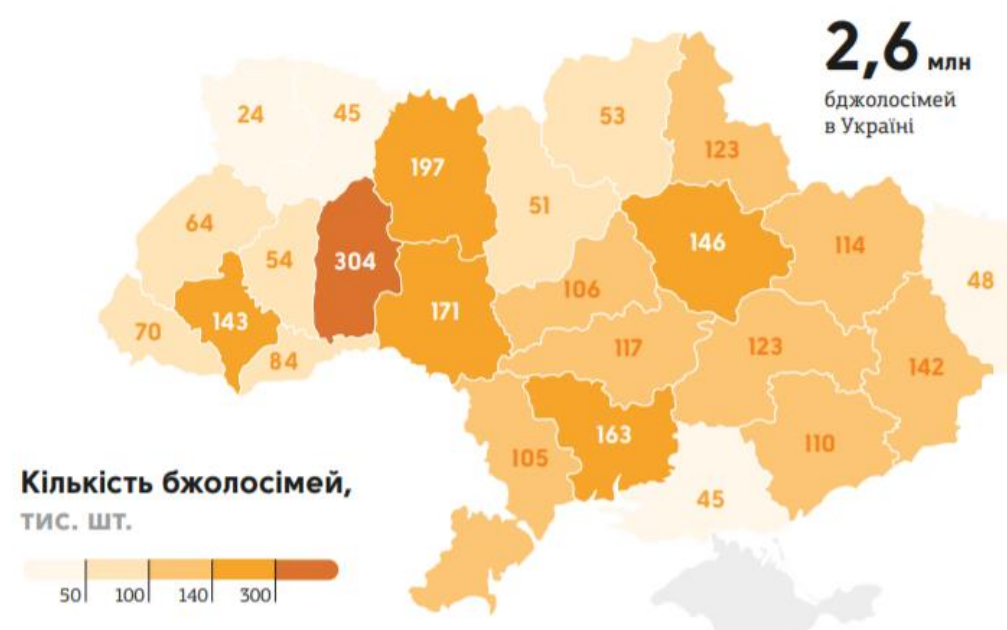

Fig. 2. Number of bee colonies in Ukraine 2019 year

As of the State Statistics Service of Ukraine and the State Fiscal Service of Ukraine.

The main advantages of beekeeping are:

1) The provision of honey, which is a valuable food;

2) The provision of beeswax, which is used in many industries, including cosmetics, polishing, pharmaceuticals and others;

3) Honeybees the best pollinators that help to increase the yield of several crops;

4) According to recent studies, honey bee venom contains a mixture of proteins that could potentially be used as a prophylactic agent to destroy HIV (human immunodeficiency virus).

At the same time, there are several problems with the market entry of honey. The EU`s institutions of food safety authorities often return honey or issue warnings to exporters, in particular, because of antibiotics contained in honey, lack of food safety certificates, or improper packaging. In addition, many importers, both in Europe and elsewhere, face honey fraud. Many market participants, as well as the International Federation of Beekeepers' Associations "Apimondia" have raised this issue.

For example, in the first half of 2019, the price of light amber honey (the main US import category) from major suppliers (such as Argentina and India) declined, while the price of Chinese honey remained very low, at around \$1.1 per kg. This is significantly lower than other suppliers. 

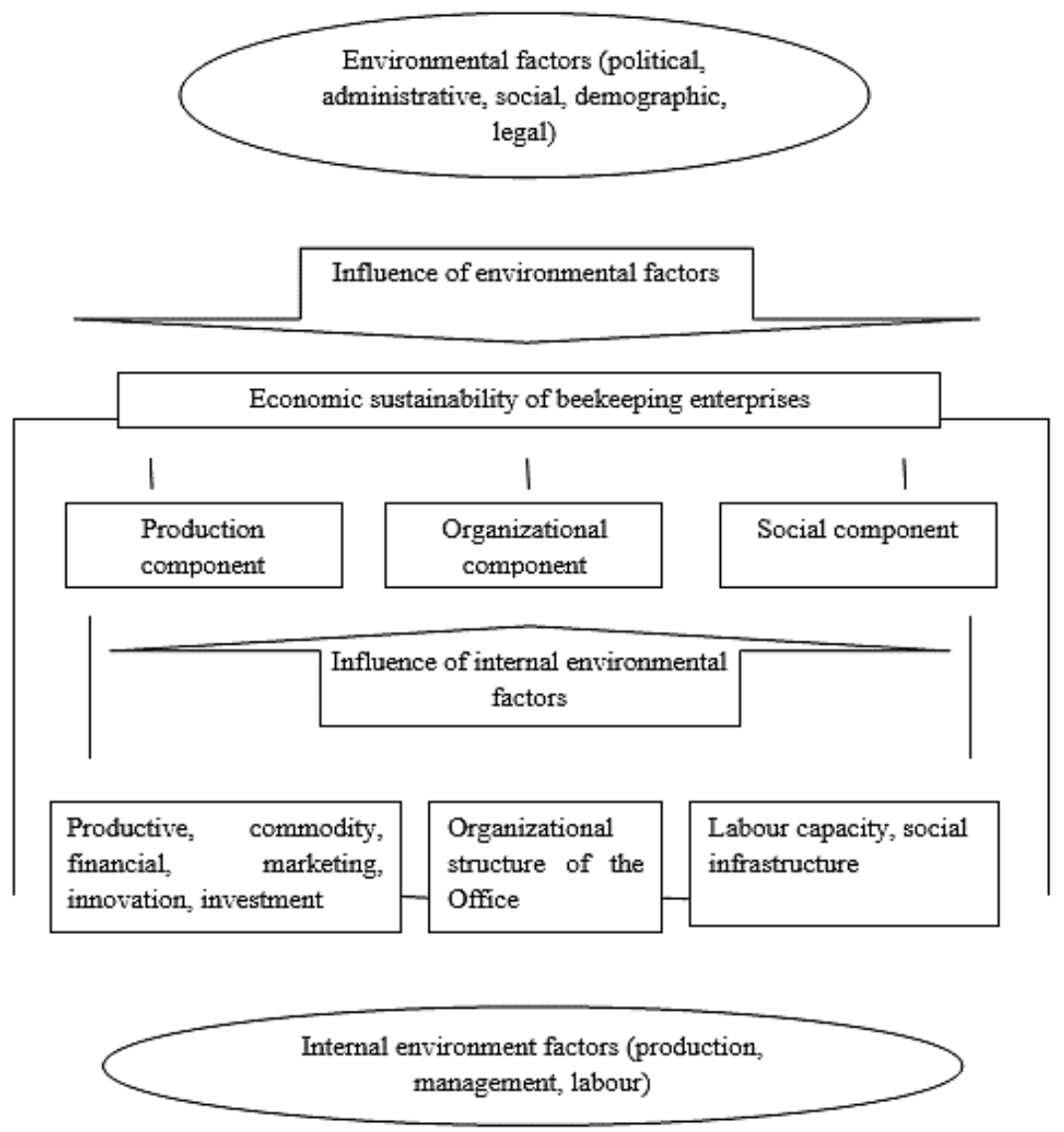

Fig. 3. Components of building economic resilience in beekeeping

\section{The main problems in the beekeeping industry of Ukraine,} which require immediate solution

1) The low technological culture of product production, processing and packaging, and the lack of industrial technology;

2) Decrease in entomophilic crops cultivation and insufficient use of bee pollination;

3) Environmental degradation and non-compliance with technological requirements for the treatment of entomophilic crops with pesticides and pests, resulting in the mass poisoning of bees;

4) Insufficient veterinary care leading to the uncontrolled spread of bee diseases; 
5) Lack of harmonized legislation on the production and quality of the products of the industry, and as a consequence of the difficulty in realizing the export potential of the industry.

Achieving an optimal balance between the desired economic growth rate and the reproduction capacity of beekeeping enterprises is a major challenge in managing economic sustainability in modern market conditions. At the same time, it is directly manifested in the enterprise's response to externalities and its ability to perform core functions effectively in a changing external environment ${ }^{15}$.

Determining the level of economic sustainability of beekeeping enterprises must take into account the depth of internal structural changes arising in response to external influences and the costs incurred in overcoming their negative impacts. The sustainable development of beekeeping enterprises is constantly being managed in the process of undermining the economic sustainability of each such enterprise, which is characterized by specific characteristics of the natural and climatic conditions of production, the location of the occurrence, depth, and duration of crisis events, the causes and possible consequences of the realization of external threats.

In general, however, the management of economic sustainability in the event of a disturbance in an enterprise's equilibrium (external and internal influences) can be described in two different ways:

1) the loss of economic viability of an enterprise occurs suddenly as a result of extraordinary events and is usually accompanied by a significant loss of assets, resulting in inconsistent financial flows, the profit of production is sharply reduced and internal conflicts and relations with business partners are exacerbated. The size of the destabilizing factors is such that the enterprise is unable to adapt to the new conditions for a long time, which increases the likelihood of its near-term bankruptcy;

2) the decline in economic stability is reflected in a relatively gradual increase in deviations from the greatest values of the main performance indicators of the enterprise and is reflected in a decrease in the volume of production, in the share of the market, in a decrease in the profitability of assets, the constant decline in the level of equity due to the emerge of permanent losses, the creation of an unsatisfactory balance sheet structure, and the fall in the market price of shares. The process begins slowly and discreetly, so it cannot be detected by traditional diagnostic methods. The lack of a rapid response to early signs of crisis in an enterprise over time leads to unregulated declines in returns and even direct losses from operations.

15 Astakhov V.P. (1995). Analysis of a firm's financial sustainability and procedures relating to bankruptcy. Os- $89.80 \mathrm{p}$. 
Deepening of crisis processes increases the failure of an enterprise to pay its current liabilities on time and in full, increasing its debt burden and dependence on external sources of financing. The reversibility of change leads to a strategic crisis, the absence of long-term success factors, and the loss of the social and economic purpose of the enterprise, which invariably leads to bankruptcy ${ }^{16}$.

In order to carry out measures to improve the economic sustainability and efficiency of bee-keeping enterprises in the future, it is necessary to set up market-appropriate economic relations and intersectoral linkages.

In order for Ukraine to participate in the international agricultural market with the production of beekeeping enterprises, it is necessary to bring domestic organizational and economic measures to develop market relations in beekeeping in line with international requirements. This is linked to the increasing role of the State as a guarantor of the exit of enterprises from the crisis and the creation of conditions for their sustainable further development. The economy of domestic beekeeping enterprises is directly related to the level of their investment. Under market conditions, only competitive enterprises, which are relatively few in numbers, can operate successfully. Foreign and domestic experience in the development of beekeeping enterprises demonstrates the high efficiency of cooperation in the sector in the complex use of bee families. In this case, depending on natural and economic influences, beekeeping companies specialize in more than one or two products.

Over the last 10-15 years, the use of bee families has been common in most countries with advanced beekeeping (USA, Australia, Japan, China, Canada, Romania, France, Ireland, etc.). Each economic actor has its own complex interrelationships. The inter-industry linkages of beekeeping are reflected in the flows of wealth - the output of each individual sector and of the social product. The cross-sectoral (vertical) links of beekeeping are characterized by a system of economic relations with a large number of different branches of the economy: industrial, processing, marketing of goods and services. The number is steadily increasing. The success of commercial firms in the production of food additives, medicines and cosmetics based on beekeeping products is particularly evident. Horizontally, these linkages encompass the relationship of beekeeping within the agricultural sphere. They are particularly close to agriculture, horticulture, vegetable production, flax cultivation, alopecia, floriculture and the like.

${ }^{16}$ Baranivska Kh.S. (2011). Features of a diagnostic system for economic sustainability as a business property. Pp. 104-110. 
The geographical differences in the natural conditions for the produce of beekeeping products determine the scope and direction of the links with their import and export, as well as the needs of beekeeping enterprises for production equipment. Favorable natural conditions and the presence of honey-bearing vegetation determine the nature of economic relations and intersectoral linkages in beekeeping enterprises. The involvement of beekeeping enterprises in the development of an interregional food market depends directly on their location and specialization. The intensity and scale of the formation of zones of specialized beekeeping enterprises should be determined by the influence of the State on price, tax and credit policies and on the development of market infrastructure. In the context of emerging markets, the principle of rational location and the combination of regional specialization in the produce of selected products, both for export and for selfsufficiency, is becoming increasingly important. The latter provides cooperation $^{17}$.

\section{Influencing factors for the effective management of the economic sustainability of beekeeping enterprises}

Beekeeping is a production and biological system that goes hand in hand with natural resources, in which case the efficiency of management of production processes in beekeeping is determined by comparing the income generated with the biological, and natural and labor resources allow making sure a certain level of economic sustainability of enterprises. In our view, the level of use of the biological and natural resources used, taking into account the ecological part, determines the efficiency of production processes in the enterprises of beekeeping. The characteristics features of beekeeping, like other branches of agriculture, much influence the efficiency of management and management in enterprises, they are divided into natural, economic, organizational, social, and environmental (fig. 3)

The production activities of beekeeping enterprises are a set of interrelated processes that depend on many components. Changes that distort the ideal structure of their interrelationships entail risks of loss of expected results, both quantitative and qualitative. The impact of these components is often sharply focused and manifests itself in performance: some elements improve performance, while others hurt the economic sustainability of beekeeping enterprises.

${ }^{17}$ Kravchenko M.V. (2015). Ensuring the economic sustainability of the beekeeping enterprises. Dnipropetrovsk: DDAEU, 205 p. 


\section{Influencing factors}

\begin{tabular}{|c|c|c|c|c|}
\hline Natural & Economic & Organizational & Social & Environmenta \\
\hline & & Components & & \\
\hline \multirow{2}{*}{$\begin{array}{l}\text { Nature and } \\
\text { Climate } \\
\text { Region. }\end{array}$} & & \multirow[b]{2}{*}{$\begin{array}{l}\text { Organizational } \\
\text { structure of the } \\
\text { administration; } \\
\text { Organizational } \\
\text { culture } \\
\text { Worker } \\
\text { education. }\end{array}$} & & \\
\hline & $\begin{array}{l}\text { Production } \\
\text { results; } \\
\text { Stockholding } \\
\text { Areas of } \\
\text { entomophilic } \\
\text { cultures and the } \\
\text { like. }\end{array}$ & & $\begin{array}{l}\text { Level of } \\
\text { supply of } \\
\text { beekeeping } \\
\text { products; } \\
\text { Employment } \\
\text { rate }\end{array}$ & $\begin{array}{l}\text { Ecological safety } \\
\text { of beekeeping } \\
\text { products; } \\
\text { The condition of } \\
\text { bees as an } \\
\text { indicator of the } \\
\text { environment. }\end{array}$ \\
\hline
\end{tabular}

\section{Fig.4. Influencing factors for the effective management}

of the economic sustainability of beekeeping enterprises

Looking at the sustainability of the enterprise itself, we note that it depends on the constituents that make the sustainability of the enterprise itself and directly or indirectly affect the sustainability of the production activities. The state of bee-keeping enterprises, where the cost, material structure of production, and sales of products offer high economic efficiency, characterizes internal sustainability. These goals can be achieved when the enterprise makes rational use of external (State policy towards agrarian law and support for beekeeping; market conditions; market infrastructure; environmental uncertainty and economic risk) and domestic (integration of the beekeeping enterprise in production and market relations expressed competence of the enterprise, level of ecological safety of production; technical and technological development of the enterprise on innovative basis; most organizational structure, the quality, and structure of production resources; the social and psychological environment in the enterprise) of the components that make it possible to get sustainable and efficient production results. The level of external sustainability is ensured by sound State regulation of the production of bee products while ensuring increased reproduction ${ }^{18}$.

${ }^{18}$ Kozachenko H.V., Voronkova A.E., Medianyk V. Iu., Nazarov V.V. (2003). Small business: sustainability and compensatory opportunities. $328 \mathrm{p}$. 
Considering that the aim of the production and economic activity of a beekeeping enterprise is to increase or keep up its productivity, as a prerequisite for a stable position in the selected market segment, and the efficient use of the resources involved, Development and expansion of activities, sustainability is regarded as the main instrument for regulating enterprise productivity, The need for continuous management of economic sustainability requires means and techniques to influence the sustainability components to raise their level. The most effective way to support an adequate level of economic sustainability is to continuously monitor changes in the external and internal environments of beekeeping businesses. The aim is to detect changes in influencing factors in time to prepare or adapt an enterprise to them.

The bees make many foods, among them: honey, propolis, wax, royal jelly, bee poison, pollen, beebread, comb capping and dead bees.

Honey is very rich in chemical composition. It has up to 300 substances and elements. The main ones are carbohydrates. Their number depends on the botanical origin of the bees, the conditions of collection and processing of the nectar. High-quality honey varieties contain up to 75 per cent of simple sugars. From nitrogen, up to 2,0 per cent of the proteins are in honey. The water content of honey is up to 18 per cent, and the water content of more than 22 per cent is called immature (table 2).

Table 2

Indicators by which the quality of honey is measured

\begin{tabular}{|l|c|c|}
\hline \multicolumn{1}{|c|}{ Rate } & \multicolumn{1}{c|}{$\begin{array}{c}\text { Top grade } \\
\text { honey }\end{array}$} & Grade I honey \\
\hline Scent & Natural, pleasant, from weak to strong \\
\hline Mass fraction of water,\% & 18,5 & 21,0 \\
\hline Renewable sugar content, $\%$ & 80,0 & 70,0 \\
\hline Weight share of sucrose, $\%$ & 3,5 & 6,0 \\
\hline $\begin{array}{l}\text { Diastasis number } \\
\text { (until free of substance) }\end{array}$ & 15,0 & 10,0 \\
\hline Content hydroxymethylfurfural. & 10,0 & 25,0 \\
\hline $\begin{array}{l}\text { Active acidity, miliequivalent } \\
\text { sodium hydroxide }\end{array}$ & 40,0 & 50,0 \\
\hline
\end{tabular}

The standard allows 2.5 per cent sucrose in honey. Vitamins are small, but very beneficial to the body. The compos of mineral substances depends on the type of honey. The most important are in the honey dark color. With enzymes, honey contains invertase, amylase, catalase, diastase, peroxidase, and others. 
When honey is heated to high temperatures or falsified, the enzymatic activity is reduced or completely lost ${ }^{19}$.

Honey is used in medicine, cosmetology and cooking. Propolis is a mixture of various substances, most commonly collected from kidneys (birch, poplar, alder, willow, and chestnut), stems and leaves of resins and balms. Bees bring adhesive mass in pollen baskets of hind feet. They are accompanied by wax, flower pollen or balm pellets of pollen grains, as well as by the secretion of the maxillary glands of bees. When removed from the nest, the propolis is infested with wood particles, insulating materials, and the bodies of bees.

Bee propolis is used as a building material for polishing wax cells, gluing frames, hulls, coating slots, narrowing flying holes, sifting through the inner surface of the beehive, etc. Due to its specific effect on micro-organisms, the nest's sanitary condition is maintained. Propolis is harvested for medical, veterinary and industrial purposes.

Bees build a nest of wax in the form of two-sided honeycombs. The honeycomb consists of hexagonal cells returned to each other by the bottom. The cells are in a nearly horizontal position, with their edges slightly raised upwards.

The wax in the form of freshly threaded honeycomb (wax) is white, and the wax produced after processing is from light to dark yellow. The wax becomes hard, fragile in the cold, and when heated it becomes soft and melts. Wax is lighter than water. It is soluble in turpentine, chloroform, gasoline and other organic substances.

The beeswax is used in medicine. It's part of some patches, ointments, creams. Wax is well absorbed by the skin and gives it a smooth and gentle appearance, so it is widely used in cosmetic medicine.

The royal jelly is the secret of honey bees that they use to feed the larvae.

The royal jelly contains essential amino acids and vitamins, but some of its benefits are lost at room temperature and by sunlight. Royal jelly from pharmacies must be kept in a cool, dark place. It is recommended to adults in hypertension, digestive disorders, stress, postpartum, skin seborrhea. It is also used to improve appetite after severe diseases as a general reinforcement agent to control blood pressure. Under the supervision of a physician, it is possible to use the preparation of a royal jelly not only for adults, but also for children and newborns.

The use of bee poison for therapeutic purposes is based on its antiinflammatory, anti-pain and desensitizing action. The healing effect of it is

${ }^{19}$ Halimov S.M. (2019). Technology of production of the beekeeping produces. Kurs lektsii. Mykolaiv : MNAU, 107 p. 
complex. It stimulates metabolism, the formation of red blood and cardiovascular activity, reduces blood pressure and cholesterol in the blood, improves sleep, appetite, healing wounds, ulcers, and acts as painkillers and anti-inflammatory; has strong bactericidal properties.

The bee poison and its preparations are used in the treatment of rheumatism, neuralgia, hypertensive disease, atherosclerosis, myocarditis, based disease, allergic and trophic diseases and lesions of the peripheral nervous system.

Thr beebread is pollen from flowers and other plants that bees have collected and treated with their enzymes. When it hits an insect, it's called a pollen load. Its value lies in the fact that the nutrient content of this beekeeping product is several times higher than that of honey. For example, in pollen load, the protein content can reach 30 per cent, which consign it to milk and meat. The beekeeper, in order to collect pollen, builds special obstacles in the hive, by which the insects shake part of the pollen into a tray.

As with any apiary product, aphids have a number of healing properties that help to overcome such serious ailments as anaemia, hypertension, nerve diseases, and endocrine-related problems ${ }^{20}$.

It restores gastrointestinal tract, liver, thyroid, improves blood circulation, reduces intoxication, and slows tumor growth. The pollen grain is absorbed as much as possible by the body, and it enhances the nutrient effect, thereby normalizing the functioning of organs. This is a unique product because it is produced by bees in limited quantities. Pollen grain cannot be artificially cultivated or counterfeited.

The pollen grain is better absorbed and more effective in the human body because of their balanced presence of biologically active substances. Pollen grain also lasts longer without losing its healing properties. Pollen grain has significantly more vitamins than pollen, especially A, B, E, K. Allergens are also destroyed by bee conversion.

The comb capping has high medicinal properties. Scientists have found that the enzyme in comb capping honey is four times larger than in regular honey and twice as large as a comb honey. Comb capping contains substances that inhibit the growth of many types of pathogens and have an antibiotic effect. It improves the metabolism of the organism, positively acts on hematopoietic, increases immunity, does not induce addiction of the pathogen to itself and is different from medicines.

The sniffles, inflammation of the nose and throat, stomatitis, tracheids, bronchitis, pneumonia, angina are treated two to three times faster with proper use than with normal medication.

${ }^{20}$ Family and home. URL: https://simya.com.ua 
In fact, every hundredth Ukrainian is a beekeeper. However, the efficiency of production remains very low. For example, there are 7,000 bees in Canada. They produce 29,000 tons of honey. There is 400,000 tons of honey in Ukraine. Only 80,000 tons of honey is produced. They produce only 400,000 tons of honey. The productivity of a beekeeper in Canada reaches 50 kilograms of honey per year, and we have between 12 kilograms and 20 kilograms. This difference in numbers is due to the fact that in Canada honey production is at an industrial level and in Ukraine it is at an amateur level.

Putting bees in cooperatives would increase the production of honey. Apiary in 3-10 beehives can only provide honey to the farmer's family. At this level, it's more of a hobby. Beekeeping becomes profitable starting with 100 beekeepers. Also, the hives themselves need to be changed. Beekeepers mainly use "Dadan" -type beehives, which are difficult to transport, and an industrial bee has to change the honey base periodically. To do this, we need to move to multi-cellular beehives, which have proven to be effective in the United States and Canada.

Moreover, the transition to an industrial level requires an improvement in quality. Therefore, beekeepers should be informed about EU quality standards. This will help reduce the use of antibiotics, shift to biodynamical production, and stop the harvesting of immature honey.

Another important factor is the regularity of the business. The EU requires that the export of honey can be traced back from its origin before indicating the apiary. All products should be have the necessary documents and standard packaging. Therefore, beekeepers should soon regularize their activities in terms of formal regulations.

Beekeeping is totally ecologically dependent. While its transformation from a hobby to an industrial business is a matter of profitability, preserving its ecosystem is a matter of industry as such.

The main reason here is plant farming, which directly affects beekeeping. Without a fertile honeybee base - plants rich in nectar and pollen - the bees will have nothing to pollinate from and where to make honey.

In addition to conserving and increasing the quantity of honey, it is also necessary to monitor the processing of their chemicals. With the pollen that they pollute, you get poor-quality honey, which will not pass certification. In addition, the bees themselves are dying because of the excessive use of chemicals.

The situation could be remedied by addressing the issue of crop pollination and chemicals treatment between the agricultural sectors. In addition, environmental authorities should start to maintain and develop the honey base.

Ukrainian beekeeping is clearly going through a period of recovery. However, if this success is short-lived, beekeepers and the State must take 
systemic steps. The former should adopt European production standards, the latter to protect the industry ${ }^{21}$.

In modern times, the country's beekeeping is greatly influenced by: State policy and its measures to regulate the agrarian market; socio-economic, environmental and some other factors. In economic literature, it is common to divide all the variety of factors into natural, material (man-made), labour and financial. Factors of production are considered to influence its status and development. The following factors of production are distinguished: structural and functional, static and dynamic, natural and monetary, natural and unnatural (artificial), industrial but not industrial. They all have a certain influence on the health and development of beekeeping enterprises. Their resources are at the heart of factors of production. In beekeeping, the most important are beekeeping, the presence and composition of honey-bearing plants, and the availability of labour, material and financial resources.

The effectiveness of beekeeping is determined by the motivation of the work, the interest of the employees of the enterprises, and is aimed at meeting the needs of society. It depends directly on the combination of production factors and the extent to which they are used in management practices. In the area of production and beekeeping, factors are a set of material, labour and social values that can be used to create labour products. Land, as an essential factor of production in bee-keeping enterprises, is represented, first, as a source of honey-bearing resources and, second, as a material substance of production and a subject of economic management. In the pre-reform methodology for bee-keeping, some economists noted the secondary importance of land, giving preference to other natural factors. So L.V. Prokofieva believes that "... the distinctive feature of beekeeping and that the land does not act here as the main means of production"22.

In beekeeping enterprises, land is both an object and a means of work, a production base for the planting of bees and the main means for the growth of honey vegetation. The topsoil is also used to grow crops, many of which feed bees, and for beekeeping is the basis of production. Land, when used wisely, has the capacity to improve its fertility.

Bee pollination, combined with the quality of other agrotechnical interventions, has an impact on the yields of entomophilous crops. The different profitability of the land is a source of differential rent I and II (by fertility and place). The servicing of crop production sectors of bee-farming is also determined by the remoteness of areas from settlements, the condition

${ }^{21}$ Beekeeping in Ukraine. URL: https://bakertilly.ua/

${ }^{22}$ Protsenko N.B. (2008). Institutional and economic mechanisms for long-term economic sustainability of industrial enterprises : avtoref. dys. ... kand. ekon. nauk, 20 p. 
of roads, the development of infrastructure, the social development of the territory and other factors. In a multi-unit economy, land as an object of ownership can be owned by different actors who can take part directly in the production process and can indirectly by granting their land rights to other land users. This is possible in land sharing, land leasing, etc ${ }^{23}$.

The improve of the economic and organizational mechanism for economic management and the saturation of the food market with the products of beekeeping is inextricably linked to the enhance of the investment attractiveness of enterprises and the development of their production and social infrastructure, as well as increasing the solvency and quality of life of the population. It has been estimated that the marketdynamic farms include large beekeeping enterprises using innovative production technologies for the integrated use of bee families. At the same time, many of the provisions of modern innovative enterprise development contain tested pre-reform periods and rational approaches to the creation of a multi-sector bee economy.

The following scientific advances for the effective use of bee families are used as the basis for the economic and mathematical modelling of prospective forms of management: apiary and integrated systems, providing for the acquisition of beekeeping season from one bee family: $20-50 \mathrm{~kg}$ of honey, $0.3-0.5 \mathrm{wax}, 3-5 \mathrm{~kg}$ of pollen, $2-3 \mathrm{~kg}$ of beebread, $200-300 \mathrm{~g}$ of propolis, $300-500 \mathrm{~g}$ of royal jelly, $4-6 \mathrm{~g}$ of bee poison, 0.5 bee packet , The required number of fruit (sterile) bee utensils and other products (discharge of bee uterus is determined by the domestic needs of the farm and market conditions). It is also provided that bee families may be contracted to pollinate entomophilic crops. Depending on the breeding technology used and the content of the bees, the output of the final product is determined by expert judgement in the study. Nomadic beekeeping (2-3 nomads per season) significantly increases the strength of bee families and multiplies the output of bees. The compilation of best management practices makes it possible to substantiate promising models of commercial organizational structures in beekeeping that are more resistant to market relations. In our opinion, three types of beekeeping enterprises and their bees are considered and have increased competitiveness.

Each of these production types is represented by a model farm (apiary), which is the most appropriate for a certain level of economic activity. Three levels of management were considered in the formulation of medium-term development prospects for the country's beekeeping (2020).

${ }^{23}$ Kravchenko M.V. (2015). Ensuring the economic sustainability of the beekeeping enterprises. Dnipropetrovsk : DDAEU, 205 p. 
The first includes the most promising model of commercial bees optimal that their size and production structure, ensuring its owners competitive, selfsufficient development under market conditions.

It is located in the territory of the administrative district for the purpose of obtaining guaranteed volumes of production, beekeeping pollination of crops and saturation of the local market with beekeeping products. The size of the apiary (100-150 bee families) provides for the most rational use of working beekeepers and apicultural assistants throughout the calendar year, as well as the use of modern mechanization devices. The second model bee is a farm that takes advantage of high-tech production. A peculiarity of the organizational mechanism of this type of production is the possibility of combining production, primary processing of products, raw materials and marketing activities into a single whole. It is expected that the beekeeping products of model farm will be sold independently in rural or regional markets, as part of harvesting and trade organizations that participate in the interregional market. Bees on farms can be used successfully to pollinate large areas of entomophilic crops on crop farms, as well as to produce themselves as a relatively large commercial production on the territory of the region. In the long run, a limited number of such bee farm can make efficient use of the honey resources of a particular area.

The third is represented by a model integrated system comprising the which includes the main enterprise and a network of apiary of various sizes and organizational and legal forms of management, as well as enterprises and organizations in the agricultural economy and other branches of the national economy, which interesting in joint activities for the production, processing and marketing of beekeeping products. The system can be territorially integrated a beekeeping area, a region and, in the long run, a representative of interregional beekeeping organizations and can act independently in the international market.

As noted by Eduard Krichfalushay, Vice President of the Association of Processors and Exporters of Honey, after the quarantine imposed by the coronavirus pandemic, falling incomes will lead to a decrease in the consumption of goods and services not of basic necessity. So the demand for honey will go down, because honey is not a necessity. First and foremost, people will be shutting down basic needs that have been delayed by the pandemic. The demand of the industry has already decreased - we already have reduced orders of industrial buyers due to the fall of sales of confectionery, cosmetics.

$\mathrm{He}$ said that the recovery of sustainable demand would not be instantaneous and that reaching previous levels would depend heavily on addressing the overall economic situation in the major consuming countries of these goods and restoring the logistics chains. 
It has been found that the situation in the domestic market for beekeeping products depends primarily on external trends. The global economic crisis has significantly unbalanced the market, but it remains one of the most dynamic and globalized today. The beekeeping market has a number of features, and in recent years there has been an active redistribution among major producers. Ukraine is among the countries that have developed bee production and are among the top five producers of honey in terms of per capita consumption and gross production. This development has been facilitated by the country's natural and climatic conditions, the large areas of honey-rich land, the traditions of the population in keeping bees, etc. Among European countries, it ranks first, but only 6 per cent of domestic honey is exported ${ }^{24}$.

An analysis of statistical data on the development of domestic beekeeping during the reporting period shows that the production of honey in all categories of farms increased by 44,9 per cent, mainly on the part of the population. The private sector accounted for 78,7 per cent in 1990. In 2013, it accounted for 98,2 per cent of the total. A negative trend can be observed in the beekeeping enterprises, where the figures were 21,3 per cent of 1,8 per cent respectively, and the number of bees and their productivity declined. The production of honey in these enterprises declined by 87,8 per cent over the study period. The relative importance of bee-keeping enterprises in the production of honey during the period under study is insignificant, which indicates that they play a small role in the develop of production of these products and in general, the reduce of production in agricultural enterprises of production as such.

An analysis of the dynamics of honey production by beekeeping companies in the various regions of Ukraine shows that Dnipropetrovsk, Vinnytsia and Kirovograd regions are in the first place in terms of production volumes. A study of the state and efficiency of the production of the main types of beekeeping products in enterprises in Dnipropetrovsk oblast confirms that, despite the growth in natural indicators, the growth of economic efficiency indicators for the period 2009-2013 has increased. Only observed in beekeeping and wax (profitability increased by 24,2 and 15,7 respectively), In the case of the main type of product, such as honey, the profitability decreased by 0,1 per cent. The level of profit from the sale of products doesn ${ }^{\prime} t$ significantly affect the overall efficiency of production in the enterprises of beekeeping in the Dnipropetrovsk region, which requires appropriate measures to be taken: in particular an integrated State approach to regulating the prices of such products, supporting and stimulating producers.

${ }^{24}$ Kravchenko M.V. (2015). Ensuring the economic sustainability of the beekeeping enterprises. Dnipropetrovsk : DDAEU, 205 p. 
Ukrainian honey is not processed and pasteurized because after six to eight months it sugars again and becomes solid. They like to consume liquid honey abroad, and our solid honey is not in demand there. It is in demand in the food industry - for the production of beer, confectionery and other products. This is one of the reasons for the conflict: beekeepers want to sell expensive at 40-45 UAH for $1 \mathrm{~kg}$, while the price for our honey based on its qualities averages from $\$ 0,9$ to $\$ 1,25$ (25-35 UAH) for $1 \mathrm{~kg}^{25}$.

Among the organizational and economic measures taken to implement the strategy for the sustainable development of beekeeping enterprises, public and investment support is important. Modern machinery and equipment needed for innovation are expensive and not always accessible to the majority of such enterprises. Therefore, one of the most important areas for the development of beekeeping enterprises is the coordinating role of the State in the area of concessional lending to various forms of cooperation: production, consumer, procurement, supply, credit and others forms ${ }^{26}$.

\section{CONCLUSIONS}

Ukraine ranks first in Europe and fifth in the world in honey production. Almost all beekeeping products are used in medicine.

One of the main problems of beekeeping is that honey is exported from Ukraine in large volumes at a low price. This can be addressed in the following ways:

1) processing honey into sweets, natural cosmetics and medicines, selling products in Ukraine and exporting abroad;

2) to use apiotherapy to treat diseases with live bees and bee products. Bees are used to pollinate crops.

As a result of the pollinate of bees, sunflower, buckwheat, fruit berries, vegetables, essential-oil and other crops, there yields increase by an average of 25-30 per cent. The cost of additional products from the pollination of crops exceeds the cost for the upkeep of the apiary.

Specialization and concentration of beekeeping are developed on the basis of interfarm cooperation. There are more than interfarm bee enterprises in Ukraine specializing in the produce of honey and other beekeeping products, as well as pollination of entomophilic crops and perennial plantations. These enterprises will determine the further development of beekeeping through the introduction of the latest science, technology, and advanced experience.

\footnotetext{
${ }^{25}$ Beehive of «facility». URL: http://day.kyiv.ua/

${ }^{26}$ Kravchenko M.V. (2015). Ensuring the economic sustainability of the beekeeping enterprises. Dnipropetrovsk : DDAEU, 205 p.
} 


\section{SUMMARY}

Purpose. To carry out a comprehensive analysis of the current state and perspective for the development of the beekeeping market in Ukraine and particularly in Kherson region. Perform a detailed analysis of the main problems of the Ukrainian beekeeping industry, which require an immediate solution and the identification of future directions for development.

Methodology/approach. The methodological basis of the research is the regulations of the economic theory, institutional theory and systemic analysis. Empirical research on the functioning of the bee market was conducted using comparative analysis, expert opinion and an evaluation procedure.

Results. The dynamics of the world output honey production were evaluated and it was established that Ukraine is included in the list of five largest honey production countries in the world. We've established an increase in the number of honey exporters. On the basis of a comparative analysis, the development of the market for bee-keeping products in various regions of Ukraine was evaluated. We have identified factors that have positive and the negative impact on the development of the beekeeping market. We have also formed a matrix of strategic choices for further development.

Originality/scientific novelty. The author's interpretation of the market of beekeeping products is presented as a system of institutions and economic relations, ensuring processes of production, exchange and consumption of foodstuffs, use of raw materials, as well as providing services the beekeeping industry.

Practical value/implications. Ecological factor need to be taken into account in order to improve the organizational and economic framework for the operation of the bee market. The determinants of development are: the skills of the personnel; the quality of domestic production and the public's confidence in it; the profitability of production; its diversification and geographical position in Ukraine; and the constraints: the ability of the population to pay; lack of reliable and statistical information. The need to develop cooperation as an important organizational and economic measure for the realization of promising areas for the development of the beekeeping market and improving its quality; provide confidence external consumers of responsible meeting their obligations; supporting the image of domestic producers.

\section{REFERENCES}

1. Pro bdzhilnytstvo [About beekeeping]. URL: https:// zakon.rada.gov.ua/

2. Halimov S.M. (2019). Tekhnolohiia vyrobnytstva produktsii bdzhilnytstva [Technology of production of the beekeeping produces]. Kurs lektsii. Mykolaiv : MNAU, 107 p. 
3. Svitovyi rynok medu ta Ukraina [The World Honey Market and Ukraine]. URL: http://www.souz-inform.com.ua/index.php?language=ukr\& menu=article/honey_market_review

4. Vitalii Kuksa (2006). Yakshcho v Ukraini ne zalyshytsia sala, yistymemo med "Dzerkalo tyzhnia" [If in Ukraine there will be no fat, we will eat honey "Mirror of the Week"], № 31.

5. Pravyla vvezennia v Ukrainu ta vyvezennia za yii mezhi bdzhil i produktiv bdzhilnytstva [Regulations on the import into and export from Ukraine of bees and bee products]. URL: https://zakon.rada.gov.ua/

6. Poriadok reiestratsii pasik [The procedure for the registration of apiary]. URL: https://zakon.rada.gov.ua/

7. Osnovni problemy bdzhilnytstva [The major problems of the beekeeping]. URL:https://aggeek.net/

8. Bdzhilnytstvo Khersonshchyny [Beekeeping of the Kherson area]. URL: https://khoda.gov.ua/

9. Bdzhilnytstvo Ukrainy [Beekeeping of the Ukraine]. URL: http://naas.gov.ua/

10. Ekonomichna Pravda [Economic truth]. URL: https:// www.epravda.com.ua/

11. V Ukraini - perevyrobnytstvo medu [Honey overproduction in Ukraine]. URL:https://agropolit.com

12. Sylna pasika [Apiary is strong]. URL:https://pasika.pp.ua/

13. Postanova Kabinetu Ministriv Ukrainy [Resolution of the Cabinet of Ministers of Ukraine]. №107 (zi zminamy). URL:http://search.ligazakon.ua/

14. Astakhov V.P. (1995). Analyz fynansovoi ustoichyvosty fyrmi y protseduri, sviazannie s bankrotstvom [Analysis of a firm`s financial sustainability and procedures relating to bankruptcy]. Os-89. $80 \mathrm{p}$.

15. Baranivska Kh.S. (2011). Osoblyvosti systemy diahnostyky ekonomichnoi stiikosti yak vlastyvosti pidpryiemstva [Features of a diagnostic system for economic sustainability as a business property]. Stratehiia ekonomichnoho rozvytku Ukrainy. Spets. vyp. 28. Pp. 104-110.

16. Kravchenko M.V. (2015). Zabezpechennia ekonomichnoi stiikosti pidpryiemstv bdzhilnytstva [Ensuring the economic sustainability of the beekeeping enterprises]. Dnipropetrovsk : DDAEU, 205 p.

17. Kozachenko H.V., Voronkova A.E., Medianyk V. Iu., Nazarov V.V. (2003). Malyi biznes: stiikist ta kompensatorni mozhlyvosti [Small business: sustainability and compensatory opportunities]. 328 p.

18. Simia i dim [Family and home]. URL: https://simya.com.ua

19. Bdzhilnytstvo $\mathrm{v}$ Ukraini [Beekeeping in Ukraine]. URL: https:// bakertilly.ua/

20. Protsenko N.B. (2008). Orhanizatsiino-ekonomichnyi mekhanizm zabezpechennia dovhostrokovoi ekonomichnoi stiikosti promyslovykh 
pidpryiemstv [Institutional and economic mechanisms for long-term economic sustainability of industrial enterprises] : avtoref. dys. ... kand. ekon. nauk, $20 \mathrm{p}$.

21. Vulyk "mozhlyvostei" [Beehive of "facility"]. URL: http:// day.kyiv.ua/

Information about the author: Averchev Oleksandr Volodymyrovych, Doctor of Agricultural Sciences, Professor at the Department of Agriculture Kherson State Agrarian and Economic University 23, Stritenska str., Kherson, Ukraine, 73006 orcid.org/0000-0002-8333-2419 